\title{
An Assessment of Flowering Dogwood (Cornus florida L.) Decline in the Eastern United States
}

\author{
Christopher M. Oswalt ${ }^{1}$, Sonja N. Oswalt ${ }^{1}$, Christopher W. Woodall ${ }^{2}$ \\ ${ }^{1}$ Forest Inventory and Analysis, United States Department of Agriculture Forest \\ Service Southern Research Station, Knoxville, USA \\ ${ }^{2}$ Forest Inventory and Analysis, United States Department of Agriculture Forest \\ Service Northern Research Station, St. Paul, USA \\ Email: soswalt@fs.fed.us
}

Received February 19 , 2012; revised March 23 $^{\text {rd }}, 2012$; accepted March 31 ${ }^{\text {st }}, 2012$

\begin{abstract}
Cornus florida $\mathrm{L}$. is one of the most numerous tree species in the Eastern United States (US). Multiple studies have reported localized declines in C. florida populations following the introduction of the destructive fungus Discula destructiva Redlin (dogwood anthracnose), but few, if any, have documented changes in C. florida populations across the species' entire natural range. Thus, a current assessment of the $C$. florida population in the Eastern US and implications for future sustainability is warranted. Our study's goal was to present $C$. florida population estimates across the natural range of the species (Little, 1971 ) in the Eastern US for two periods based on state-level forest land inventories conducted by the US Department of Agriculture Forest Service, Forest Inventory and Analysis (FIA) program. Rangewide, C. florida populations declined by approximately $49 \%$ over the time periods studied. At the State level, population declines occurred in 17 out of 30 states and biomass declines occurred in 20 out of 30 states studied. While declines were widespread in the substate units surrounding the Appalachians, the largest declines appeared to be centered within the Appalachian ecoregion.
\end{abstract}

Keywords: Forest Inventory; Population Decline; Tree Disease; Discula destructiva

\section{Introduction}

Cornus florida L. (flowering dogwood) is widely distributed across the eastern landscape of the United States (US) and is one of the most common understory trees in North America (Jenkins \& White, 2002). Little (1971) describes the C. florida geographical distribution as covering the majority of the Eastern US from northern Florida and the Gulf Coast to southern Michigan and New England and extending as far west as eastern Oklahoma and eastern Texas. Although C. florida is an important member of the eastern deciduous forest, the species has been and is currently experiencing localized and regional declines. Cornus florida declines have largely been attributed to an imported fungus (Britton, 1994). The fungus Discula destructiva Redlin (dogwood anthracnose) (Mielke \& Langdon, 1986; Redlin, 1991; Chellimi et al., 1992) has been identified as responsible for considerable $C$. florida mortality throughout the East, particularly in the Appalachian ecoregion (Oswalt \& Oswalt, 2010).

Botanical surveys conducted throughout the $20^{\text {th }}$ Century have documented the abundance of $C$. florida in the Eastern US (Hiers \& Evans, 1997). Measures of high relative density and elevated importance values prior to $D$. destructiva infestation were reported by Hannah (1993) in North Carolina, Quarterman et al. (1972) in Tennessee, Muller (1982) in Kentucky, Carr and Banas (2000) in Virginia, and Sherald et al. (1996) in Maryland. Moreover, C. florida has been documented as a common component of second-growth hardwood stands (Orwig \& Abrams, 1994; Jenkins \& Parker, 1998), as an important understory component of old-growth forests (McCune et al.,
1988; Goebel \& Hix, 1996), and is also reported to be a significant source of calcium, in the form of leaf litter, in the surface horizons of some forest soils (Thomas, 1969; Hepting, 1971).

Multiple studies (Hiers \& Evans, 1997; Schwegman et al., 1998; Williams \& Moriarty, 1999; McEwan et al., 2000) have reported substantial $C$. florida mortality at local scales across its natural biological range following local colonization by $D$. destructiva, the causal agent for dogwood anthracnose (Redlin, 1991). While numerous studies have quantified local losses of C. florida (Sherald et al., 1996; Hiers \& Evans, 1997; Schwegman et al., 1998; Williams \& Moriarty, 1999; Carr \& Banas, 2000; McEwan et al., 2000) specifically attributed to $D$. destructiva, few, if any, studies have quantified large-scale losses across the entire range of $C$. florida. Given that $C$. florida is one of the most numerous tree species in the Eastern U.S. (Woodall et al., 2010), a current assessment of the C. florida population in the Eastern US and implications for future sustainability is warranted. While $D$. destructiva is a known pathogen that has had documented negative impacts on $C$. florida populations, the decline of $C$. florida is ultimately a combination of numerous causal agents, including inter-and intraspecific competition, defoliators, and a lack of management or restoration of the species. Setting aside the complexities of abiotic and biotic decline agents, much can be gained from a strategic-scale assessment of $C$. florida population changes known to be experiencing localized declines using comparisons of large-scale forest inventories. Hence, our study's goal was to present $C$. florida population estimates across the natural range of the species (Little, 1971) in the Eastern US for two periods 
based on state-level forest land inventories conducted by the US Department of Agriculture (USDA) Forest Service, Forest Inventory and Analysis (FIA) program. Our specific objectives were to: (1) quantify current $C$. florida populations in the Eastern US, (2) quantify change, if any, in C. florida populations for the period beginning in the early 1980s to 2007 and (3) identify regional and spatial trends in C. florida population shifts for the same period.

\section{Materials and Methods}

\section{Data}

The forest inventory conducted by FIA is a year-round effort to collect and disseminate information and statistics on the extent, condition, status and trends of forest resources across all ownerships (Smith, 2002). In the late 1990s, FIA began a transition from irregular and asynchronous periodic inventories to annual inventories (Bechtold \& Patterson, 2005). Before 2000, most inventories were periodic; since 2000 most states have been inventoried annually. FIA applies a nationally consistent sampling protocol using a quasisystematic design covering all ownerships in the entire Nation (Bechtold \& Patterson, 2005). For this study, data was collected across 41 FIA regional units among 13 states. Fixed-area plots were installed in locations with accessible forest land cover (Bechtold \& Patterson, 2005). Field crews collected data on $>300$ variables, including land ownership, forest type, tree species, tree size, tree condition, and other site attributes (e.g., slope, aspect, disturbance, land use) (Smith, 2006; US Department of Agriculture, 2004). Plot intensity for field collected data was approximately one plot for every 2400 ha (6000 acres) of land (125,000 plots nationally).

The design for FIA inventory plots consists of four $7.3 \mathrm{~m}$ fixed-radius subplots spaced $36.6 \mathrm{~m}$ apart in a triangular arrangement with one subplot in the center (Bechtold \& Patterson, 2005). All trees with a diameter at breast height (d.b.h.) of at least $12.7 \mathrm{~cm}$ are inventoried on forested subplots. A $2.1 \mathrm{~m}$ radius microplot, offset $3.7 \mathrm{~m}$ from subplot center, is established within each subplot. All live tree seedlings are tallied according to species within each microplot. Conifer seedlings must be at least $15.2 \mathrm{~cm}$ in length with a root collar diameter < $2.54 \mathrm{~cm}$ to qualify for measurement. Hardwood seedlings must be at least $3.5 \mathrm{~cm}$ in length with a root collar diameter $<2.54$ $\mathrm{cm}$ to qualify for measurement.

Data were assembled from the USDA Forest Service, FIA database (FIADB) version 3.0 in May 2009 (US Department of Agriculture, 2006). The FIADB contains both current and historic inventory data related to the forest resources of the US (Reams et al., 2005). County level estimates of C. florida populations (number of all live trees $>2.54 \mathrm{~cm}$ d.b.h.) and total C. florida biomass (tons of all live trees $>2.54 \mathrm{~cm}$ d.b.h.) were generated for all states (except Oklahoma) within the historic range of C. florida (Little, 1971) from FIA plot data for two periods in time and labeled time 1 and time 2 (Table 1). Perfect alignment of inventory dates was not possible due to the nature of past periodic inventories and variability in transition times between periodic and annual inventory designs (Bechtold \& Patterson, 2005). Similarly, county-level population estimates were necessary because of the lack of complete plot alignment due to an altered plot design (variable radius to fixed radius) between periodic and annual inventory implementation. The data labeled time 1 ranged from 1983 in Nebraska to 1995 in Arkansas and Maine (Table 1) roughly corresponds to the time around which $D$. destructiva was first identified as a causal agent for dogwood anthracnose (Mielke \& Langdon, 1986; Redlin, 1991; Chellemi et al., 1992), and represents a time period early in the spread of the disease. The data labeled time 2 was less variable and ranged from 2005 to 2007. Individual counties were assigned to FIA substate units that correspond to both political and ecological boundaries (Figure 1).

Table 1.

State and inventory data selected for analysis by time period grouping.

\begin{tabular}{|c|c|c|}
\hline \multirow{2}{*}{ State } & Time 1 & Time 2 \\
\hline & periodic & annual \\
\hline Alabama & 1990 & 2007 \\
\hline Arkansas & 1995 & 2007 \\
\hline Connecticut & 1985 & 2006 \\
\hline Delaware & 1986 & 2006 \\
\hline Florida & 1987 & 2007 \\
\hline Georgia & 1989 & 2007 \\
\hline Illinois & 1985 & 2007 \\
\hline Indiana & 1986 & 2007 \\
\hline Iowa & 1990 & 2007 \\
\hline Kansas & 1994 & 2007 \\
\hline Kentucky & 1988 & 2006 \\
\hline Louisiana & 1991 & 2005 \\
\hline Maine & 1995 & 2006 \\
\hline Maryland & 1986 & 2006 \\
\hline Massachusetts & 1985 & 2006 \\
\hline Michigan & 1993 & 2007 \\
\hline Minnesota & 1990 & 2007 \\
\hline Mississippi & 1994 & 2006 \\
\hline Missouri & 1989 & 2007 \\
\hline Nebraska & 1983 & 2007 \\
\hline New Jersey & 1987 & 2006 \\
\hline New York & 1993 & 2006 \\
\hline North Carolina & 1984 & 2006 \\
\hline Ohio & 1991 & 2006 \\
\hline Pennsylvania & 1989 & 2006 \\
\hline Rhode Island & 1985 & 2006 \\
\hline South Carolina & 1986 & 2007 \\
\hline Tennessee & 1989 & 2007 \\
\hline Texas & 1992 & 2007 \\
\hline Virginia & 1984 & 2007 \\
\hline West Virginia & 1989 & 2006 \\
\hline
\end{tabular}




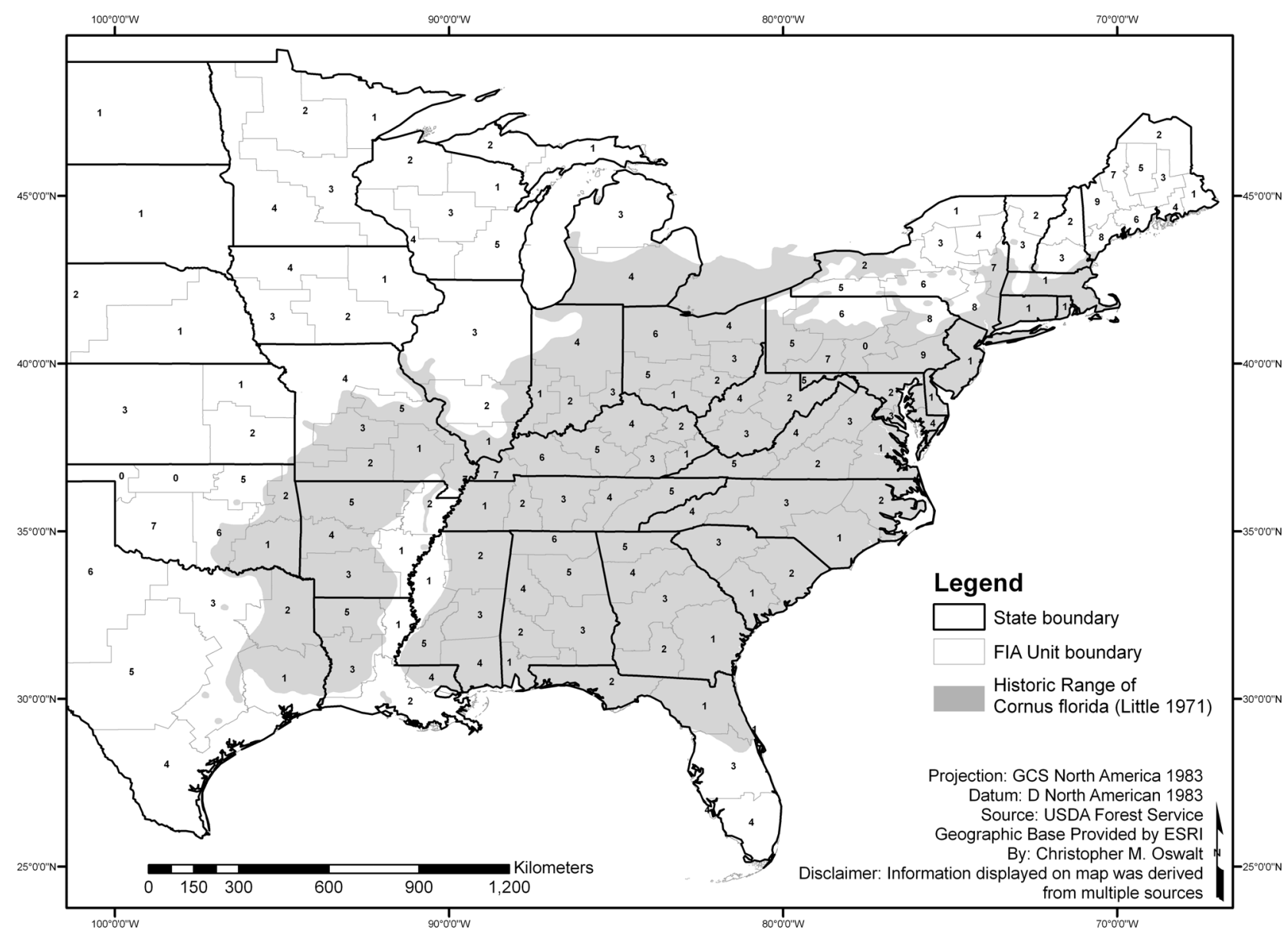

Figure 1.

Historic range of Cornus florida (L.) shown with state boundaries and Forest Inventory and Analysis (FIA) units (see Table A5 for unit code descriptions).

\section{Analysis}

Absolute change, percent change and annual change was calculated for each county. Annual change was calculated by dividing the difference between times 1 and 2 for each county by the remeasurement period. Paired $t$-tests pairing county-level estimates at times 1 and 2 using R (R Development Core Team, 2009) were used to identify significant changes in C. florida tree populations and total biomass rangewide and within states and regional (FIA) units between times 1 and 2. Additional paired $t$-tests were used to test for significant changes in tree populations and total biomass within $5.1 \mathrm{~cm}$ diameter classes rangewide. Biomass estimates were converted to metric equivalents post-analysis.

\section{Results}

\section{Rangewide}

No C. florida stems were sampled in the states of Vermont, New Hampshire or Wisconsin for the two periods represented in this study. The rangewide C. florida population in the Eastern US declined approximately 49\% $(P<.0001)$ from an estimated 9.3 billion trees at time 1 to an estimated 4.7 billion trees at time 2 (Table A1). Mean annual change among all states within the historic range of $C$. florida equates to losses of approximately 8.6 million trees year $^{-1}$ over the period of this study. Total biomass (Mg) declined approximately 58\% (P $<.0001$ ) from 10.0 million $\mathrm{Mg}$ to 41.8 million $\mathrm{Mg}$ from time 1 to time 2, respectively (Table A1). Mean annual change was approximately $-112,418 \mathrm{Mg} \cdot$ year $^{-1}$ among all states. All $C$. florida stems sampled in times 1 and 2 were in the $35.6 \mathrm{~cm}$ diameter class or smaller (Table A2). Significant declines in the total number of $C$. florida stems occurred between time periods for the $5.1,1.2,15.2$, and $2.3 \mathrm{~cm} \mathrm{(2,} \mathrm{4,} 6$ and 8 in.) diameter classes $(P<.0001,<.0001,<.0001,<.0001$, respectively), while significant declines in biomass were identified in the 5.1, 1.2, 15.2, 2.3, and $25.4 \mathrm{~cm}(2,4,6,8$, and $10 \mathrm{in}$.) diameter classes $(P<.0001,<.0001,<.0001,<.0001,=.0075$, respectively). The relative declines in biomass were slightly larger than declines in the number of stems for each of the 5.1 cm (2 in.) diameter classes (Table A3). What appeared to be large relative increases in the $35.6 \mathrm{~cm}$ (14 in.) diameter class were not significant for either number of stems or dry biomass $(P=.1507$ and $=.2489$, respectively $)$.

\section{State Level}

Seventeen out of 30 eastern states experienced significant declines in C. florida populations, while 20 states experienced 
significant declines in dry biomass (Table A4). The largest absolute declines in numbers of stems, calculated as mean county change, occurred in Alabama, followed by West Virginia, Virginia, North Carolina and Tennessee with losses of 8.1, 7.5, 6.0, 5.8 and 5.0 million trees, respectively (all p values $<.0001)$. Cornus florida biomass declines were also largest in Alabama (Table A4). Maryland ( $P=.0038$ ) was the only state where a significant increase in biomass was observed. No significant increases in numbers of trees were observed. Cornus florida was sampled only for time 1 in Kansas, Maine and Nebraska and, therefore, relative losses appeared to be $100 \%$ (Table A1), although not significant (Table A4). The largest relative declines in numbers of trees from time 1 to time 2 were observed in West Virginia $(-73 \% ; P<.0001)$, Ohio $(-71 \% ; P$ $<.0001)$, Maryland (-66\%; $\mathrm{P}=.0043)$ and Pennsylvania $(-64 \%$; $P<$.0001) (Table A1). The largest significant relative declines in biomass occurred in New York $(-71 \% ; P=.0194)$, Ohio $(-70 \% ; P<.0001)$, Mississippi $(-69 \% ; P<.0001)$, Virginia $(-68 \% ; P<.0001)$ and North Carolina $(-67 \% ; P<.0001)$ (Table A1).

\section{Substate Level}

Cornus florida stems were recorded in 107 FIA units in either times 1 or 2 or at both times (Table A5). Significant declines in numbers of stems were observed in 57 units (53\%). Dry biomass declined in 55 (51\%) of the 105 FIA units. Significant declines in both numbers of stems and dry biomass were detected in 48 units (45\%). The largest regional declines in number of stems were in southwest-north Alabama $(-16.4$ million trees county $\left.^{-1}, P=.0035\right)$ and southern West Virginia (-13.9 million trees county $\left.^{-1}, P<.0001\right)$. Biomass loss was greatest in southwest-north Alabama $\left(-244,723 \mathrm{Mg} \cdot\right.$ county $^{-1}, P$ $=.0105)$ and west central Alabama $\left(-188,035 \mathrm{Mg} \cdot\right.$ county $^{-1}, P$ $<$.0023). Losses, both in terms of number of stems and biomass, appeared to be heaviest within the Appalachian Mountains and surrounding area. Interestingly, significant regional increases in number of stems $(P=.0280)$ and biomass $(P=.0294)$ were observed in the South Delta unit in Louisiana which is outside of the geographic distribution delineated by Little (1971).

The largest substate declines relative to the time 1 population occurred in New York. The Adirondack and South-central Highlands units experienced a $100 \%$ loss of $C$. florida stems $(P$ $=.0419$ and $=.0233$, respectively). Sixteen percent of all substate units experienced calculated declines of $>75 \%$. Calculated relative declines in excess of $50 \%$ were recorded in $53 \%$ of all FIA units. Relative increases in stem numbers, regardless of statistical significance, were observed in $16 \%$ of units. Significant increases in numbers of stems were observed in the Southwestern Ozarks of Missouri $(P=.0193)$ and in the South Delta of Louisiana $(P=.0280)$.

\section{Discussion}

The results of this investigation suggest that $C$. florida populations have declined significantly across the Eastern US Declines in absolute numbers of trees have been particularly noticeable in the Appalachians and in the South. Losses relative to population levels during the period of 1983-1995 (time 1) appeared larger in the North. One reason for this may be that the majority of the data for time 1 was collected in the late 1980s and early 1990s. Symptoms of what was once labeled "lower branch dieback” (Daughtrey \& Hibben, 1983) but eventually described as D. destructiva (Redlin, 1991) were first recognized in New York in the spring of 1979 (Daughtrey et al., 1996). Therefore, many stems could have succumbed to $D$. destructiva and not have been sampled in the northern FIA inventories during the late 1980s. However, the southern FIA inventories may not have been impacted due to the lag time that would result from the movement of $D$. destructiva migration southward.

This analysis does not discriminate among causal agents of $C$. florida mortality. However, with declines correlating geographically with the known $D$. destructiva distribution coupled with numerous localized investigations implicating $D$. destructiva in significant $C$. florida losses, it can be assumed that $D$. destructiva has had a significant impact on populations in the region. While the assumption of the authors is that a significant amount of the $C$. florida declines revealed by this investigation can be attributed to the impacts of the fungus $D$. destructiva, other factors are likely to have played some role, particularly in states where $D$. destructiva has not been identified as problematic (e.g., Mississippi). For example, Pierce (2001), in Indiana, attributed $C$. florida mortality to competition with Acer saccharum and mediated by fire suppression activities. In Kentucky, McEwan et al. (2000) reported a 36\% decline in C. florida density in an old-growth stand prior to the documentation of $D$. destructiva in the area. While it is possible $D$. destructiva was present without having been documented, McEwan et al. (2000) suggested that factors such as canopy closure, drought, and natural canopy-gap dynamics may have been an important factor. That theory is supported by a study by Oswalt and Oswalt (2010), which found that changes in C. florida populations were significantly related to changes in all live volumes of forest density. The well documented deleterious impacts of $D$. destructiva, however, cannot be ignored. According to reports from Anderson (1991) and Knighten and Anderson (1992, 1993), D. destructive-mediated C. florida mortality increased from $0 \%$ to 23\% in the Appalachians between 1988 and 1993. Concomitantly, the area estimated to be infected with $D$. destructiva increased from 0.2 to 7.0 million ha over the same period (Daughtrey et al., 1996). Moreover, Windham et al. (1993) reported widespread infection and rapid die-off of $C$. florida throughout the Great Smoky Mountains National Park in the early 1990s.

While the declines in $C$. florida populations were significant for this study, loss estimates were generally lower than many of the documented studies at much smaller scales. For example, while the results of this study suggested losses of approximately $60 \%$ of the $C$. florida population in east Tennessee and $74 \%$ on the Cumberland Plateau, Hiers and Evans (1997) reported C. florida declines of approximately $98 \%$ from $C$. florida population estimates first reported by McGee (1986) in Tennessee. Myers et al. (2004) observed significant declines of C. florida, also on the Cumberland Plateau, and documented the species' complete disappearance from the subcanopy on their study site. The current study suggests that while the loss amounted to approximately $74 \%$ of the C. florida population, declines averaged $>10$ million stems per county on the Cumberland Plateau between times 1 and time 2 (Table 1). The loss of C. florida on the Cumberland Plateau in Tennessee during the period of this study was approximately 170 million trees.

In Maryland, C. florida declines averaged between 56 and $79 \%$ among four regions between times 1 and 2. Sherald et al. 
(1996) documented C. florida mortality at approximately $77 \%$ between 1976 and 1992. Regional relative declines of $C$. florida populations in Pennsylvania ranged from $63 \%$ to $82 \%$ with no change in mean county-level populations estimates in the North Central Allegheny region. Williams and Moriarty (1999) reported $C$. florida mortality in the northern Allegheny Plateau of between $58 \%$ and $68 \%$. The lack of significant change in some parts of the Allegheny region could be a result of the lower densities of $C$. florida documented in the area (Williams \& Moriarty, 1999). In some areas, the lack of significant change was possibly due to a limited number of counties in some regional FIA units (e.g., Western unit in Maryland has two counties).

It is important to note that the estimates reported here for the period 1983 to 1995 (time 1) were generated during a time when FIA implemented periodic inventories. The estimates generated for the period 2005-07 (time 2) were generated from the FIA program's annual inventory design (Bechtold \& Patterson, 2005). As a result, additional uncertainty is introduced when comparing estimates across time. However, analyses at broad scales, such as the one here, reduce the probability of the additional uncertainty significantly influencing the results. Fei and Steiner (2007) used similar methods (time 1 data was from periodic inventories and ranged from 1980-1995 while time 2 data was from annual inventories with a much smaller range) to identify large-scale increases in Acer rubrum populations in eastern forests. Regional differences as a result of FIA organizational structure between the North and South are recognized during implementation of both the periodic and annual inventories. However, focus on tree level variables minimizes the impact of such differences.

Given the documented range of dogwood prior to 1971 (Little, 1971) and its substantial decline from the 1980s to the present, we hypothesize that future dogwood populations will continue to wane. The deleterious effects of $D$. destructiva, combined with inter- and intra-specific competition, defoliators, and little emphasis on restoration and management engenders little hope for slowing the decline of $C$. florida populations on the landscape. Additionally, climate change effects might be expected to negatively affect $C$. florida populations. The relatively widespread $C$. florida range could ensure its stability in limited southern locations, while the majority of its extent in the middle and high latitudes may face increased competition due to climate-change induced species migration (Woodall et al., 2009). Some evidence from this study suggests that range shifts may already be occurring in C. florida populations given that the greatest losses in biomass occurred in the species' northern range and greatest gains occurred in its southern range. However, range shifts were not the focus of this study and further investigation and monitoring over time will be necessary to corroborate those initial observations. Although the future range and magnitude of $C$. florida populations is uncertain, the need for continued monitoring and proactive approaches to restoration and management is evident.

\section{Conclusion}

While declines were widespread in the substate units surrounding the Appalachians, the largest declines appeared to be centered within the Appalachian ecoregion. These results indicate that an important component of the eastern deciduous forest may be suffering serious declines. Our results support many smaller, localized investigations of $C$. florida mortality as well as large quantities of anecdotal evidence that has been accumulated over time. Cornus florida has been an important tree species in the Appalachian ecoregion. Faced with large-scale declines in populations of $C$. florida, particularly in the midstory of eastern deciduous forests, further expansion of generalist species such as $A$. rubrum may be expected to occur. The need for continued monitoring and proactive restoration and management goals for $C$. florida is evident.

\section{Acknowledgements}

The authors thank the USDA Forest Service Southern Research Station (SRS) and Northern Research Station (NRS) for funding and support for this project. We also acknowledge the hard work and dedication of SRS and NRS field crews.

\section{REFERENCES}

Anderson, R. L. (1991). Results of the 1990 dogwood anthracnose impact assessment and pilot test in the southeastern United States. Protection Report R8-PR 20. Atlanta, GA: US Department of Agriculture Forest Service, Southern Region.

Bechtold, W. A., \& Patterson, P. L. (2005). The enhanced forest inventory and analysis program-National sampling design and estimation procedures. General Technical Report SRS-80. Asheville, NC: US Department of Agriculture Forest Service, Southern Research Station.

Britton, K. O. (1994). Dogwood anthracnose. In C. Ferguson, \& P. Bowman (Eds.), Threats to forest health in the southern Appalachians (pp. 17-20). Gatlinburg, TN: Southern Appalachian Man and the Biosphere Co-operative.

Carr, D. E., \& Banas, L. E. (2000). Dogwood anthracnose (discula destructiva): Effects of and consequences for host (Cornus florida) demography. American Midland Naturalist, 143, 169-177. doi:10.1674/0003-0031(2000)143[0169:DADDEO]2.0.CO;2

Chellemi, D. O., Britton, K. O., \& Swank, W. T. (1992). Influence of site factors in dogwood anthracnose in the Nantahala Mountain range of western North Carolina. Plant Disease, 76, 915-918. doi:10.1094/PD-76-0915

Daughtrey, M. L., \& Hibben, C. R. (1983). Lower branch dieback, a new disease of northern dogwoods. Phytopathology, 73, 365.

Daughtrey, M. L., Hibben, C. R., Britten, K. O., Windham, M. T., \& Redlin, S. C. (1996). Dogwood anthracnose, understanding a disease new to North America. Plant Disease, 80, 349-358. doi:10.1094/PD-80-0349

Fei, S., \& Steiner, K. C. (2007). Evidence for increasing red maple abundance in the eastern United States. Forest Science, 53, 473-477.

Goebel, P. C., \& Hix, D. M. (1996). Development of mixed-oak forests in southeastern Ohio: A comparison of second-growth and oldgrowth forests. Forest Ecology and Management, 84, 1-21. doi:10.1016/0378-1127(96)03772-3

Hannah, P. R. (1993). Composition and development of two Appalachian hardwood stands in North Carolina. Journal of the Elisha Mitchell Scientific Society, 109, 87-98.

Hepting, G. H. (1971). Diseases of forest and shade trees of the United States. Agriculture Handbook, US Department of Agriculture, Washington DC.

Hiers, J. K., \& Evans, J. P. (1997). Effects of anthracnose on dogwood mortality and forest composition of the Cumberland Plateau (USA). Conservation Biology, 11, 1430-1435. doi:10.1046/j.1523-1739.1997.97009.x

Holzmueller, E., Jose, S., Jenkins, M., Camp, A., \& Long, A. (2006). Dogwood anthracnose in eastern hardwood forests: What is known and what can be done? Journal of Forest, 104, 21-26.

Jenkins, M. A., \& Parker, G. R. (1998). Composition and diversity of woody vegetation in silvicultural openings of southern Indiana forests. Forest Ecology and Management, 109, 57-74. 
doi:10.1016/S0378-1127(98)00256-4

Jenkins, M. A., \& White, P. S. (2002). Cornus florida L. mortality and understory composition changes in western Great Smoky Mountains National Park. Journal of the Torrey Botanical Society, 129, 194206. doi: $10.2307 / 3088770$

Knighten, J. L., \& Anderson, R. L. (1992). Results of the 1991 dogwood anthracnose impact assessment and pilot test in the southeastern United States. Protection Report R8-PR 23, US Department of Agriculture Forest Service, Southern Region.

Knighten, J. L., \& Anderson, R. L. (1993). Results of the 1992 dogwood anthracnose impact assessment and pilot test in the southeastern United States. Protection Report R8-PR 24, US Department of Agriculture Forest Service, Southern Region.

Little, E. L. Jr. (1971). Atlas of United States trees, volume 1, conifers and important hardwoods. US Department of Agriculture Miscellaneous Publication 1146.

McCune, B., Cloonan, C. L., \& Armentano, T. V. (1988). Tree mortality and vegetation dynamics in Hemmer Woods, Indiana. American Midland Naturalist, 120, 416-431. doi:10.2307/2426014

McEwan, R. W., Muller, R. N., Arthur, M. A., \& Housman, H. H. (2000). Temporal and ecological patterns of flowering dogwood mortality in the mixed mesophytic forests of eastern Kentucky. Journal of the Torrey Botanical Society, 127, 221-229. doi:10.2307/3088759

McGee, C. E. (1986). Loss of Quercus spp. dominance in an undisturbed old-growth forest. Journal of the Elisha Mitchell Scientific Society, 102, 10-15.

Mielke, M. and Langdon, K. (1986). Dogwood anthracnose fungus threatens Catoctin Mountain Park. Park Science, 6, 6-8.

Muller, R. N. (1982). Vegetation patterns in the mixed mesophytic forest of eastern Kentucky. Ecology, 63, 1901-1917. doi:10.2307/1940129

Myers, B. R., Walck, J. L., \& Blum, K. E. (2004). Vegetation change in a former chestnut stand on the Cumberland Plateau of Tennessee during and 80-year period (1921-2000). Castanea, 69, 81-91. doi:10.2179/0008-7475(2004)069<0081:VCIAFC >2.0.CO;2

Omernik, J. M. (1987). Ecoregions of the conterminous United States. Map (scale 1:7,500,000). Annals of the Association of American Geographers, $77,118-125$.

Orwig, D. A., \& Abrams, M. D. (1994). Land-use history (1720-1992), composition, and dynamics of oak-pine forests within the Piedmont and Coastal Plain of northern Virginia. Canadian Journal of Forest Research, 24, 1216-1225. doi:10.1139/x94-160

Oswalt, C. M., \& Oswalt, S. N. (2010). Documentation of significant losses in Cornus florida L. populations throughout the Appalachian ecoregion. International Journal of Forestry Research, 2010. doi:10.1155/2010/401951.

Pierce, A. A. (2001). Population dynamics of flowering dogwood (Cornus florida L.) and community structure at the Ross biological reserve. M.S. Thesis, West Lafayette, IN: Purdue University.

Quarterman, E., Turner, B. H., \& Hemmerly, T. E. (1972). Analysis of virgin mixed mesophytic forests in Savage Gulf, Tennessee. Bulletin of the Torrey Botanical Club, 99, 228-232. doi:10.2307/2484607

$\mathrm{R}$ Development Core Team (2009). R: A language and environment for statistical computing. R Foundation for Statistical Computing, Vienna. http://www.R-project.org

Reams, G. A., Smith, W. D., Hansen, M. H., Bechtold, W. A., Roesch, F. A., \& Moisen, G. G. (2005). The forest inventory and analysis sampling frame. General Technical Report SRS-80, Asheville, NC: US Department of Agriculture Forest Service, Southern Research Station.

Redlin, S. C. (1991). Discula destructiva sp. nov., cause of dogwood anthracnose. Mycologia, 83, 633-642. doi:10.2307/3760218

Schwegman, J. E., McClain, W. E., Esker, T. L., \& Ebinger, J. E. (1998). Antracnose-caused mortality of flowering dogwood (Cornus florida L.) at Dean Hills Nature Preserve, Fayette County, Illinois, USA. Natural Areas Journal, 18, 204-207.

Sherald, J. L., Stidham, T. M., Hadidian, J. M., \& Hoeldtke, J. E. (1996). Progression of the dogwood anthracnose epidemic and the status of flowering dogwood in Catoctin Mountain Park. Plant Disease, 80, 310-312. doi:10.1094/PD-80-0310

Smith, W. B. (2002). Forest inventory and analysis: A national inventory and monitoring program. Environmental Pollution, 116, 233242. doi:10.1016/S0269-7491(01)00255-X

Smith, W. B. (2006). An overview of inventory and monitoring and the role of FIA in national assessments. Proceedings RMRS-P=42CD. Fort Collins, CO: US Department of Agriculture Forest Service, Rocky Mountain Research Station.

Thomas, W. A. (1969). Accumulation and cycling of calcium by dogwood trees. Ecological Monographs, 39, 101-120. doi:10.2307/1950739

US Department of Agriculture (2004). Field instructions for southern forest inventory. Unpublished report. Knoxville, TN: Southern Research Station, Forest Inventory and Analysis.

US Department of Agriculture (2006). FIA field methods for phase 3 measurements. Version 3.0. Arlington, VA: US Department of Agriculture Forest Service, Forest Inventory and Analysis Program. http://fia.fs.fed.us/library/field-guides-methods-proc

Williams, C. E., \& Moriarity, W. J. (1999). Occurrence of flowering dogwood (Cornus florida L.) mortality by dogwood anthracnose (Discula destructiva Redlin), on the northern Allegheny Plateau. Journal of the Torrey Botanical Society, 126, 313-319. doi:10.2307/2997315

Windham, M. T., Montgomery-Dee, M. E., \& Parham, J. (1993). Site parameters that affect dogwood anthracnose incidence and severity. In B. L. James (Ed.), Proceedings of the 38th Southern Nursery Research Conference (pp. 184-187). Marietta, GA: Southern Nurserymen's Association.

Woodall, C. W., Oswalt, C. M., Westfall, J. A., Perry, C. H., \& Nelson, M. D. (2009). Tree migration detection through comparisons of historic and current forest inventories. Proceedings RMRS-P-56CD. Fort Collins, CO: US Department of Agriculture Forest Service, Rocky Mountain Research Station.

Woodall, C. W., Oswalt, C. M., Westfall, J. A., Perry, C. H., Nelson, M. D., \& Finley, A. O. (2010). Selecting tree species for testing climate change migration hypotheses using forest inventory data. Forest Ecology and Management, 259, 778-785. doi:10.1016/j.foreco.2009.07.022 


\section{M. OSWALT ET AL.}

\section{Appendix}

Table A1.

Estimates of the number of trees (a) and aboveground biomass (b) of dogwood for times 1 and 2 along with sampling error, annualized and relative change for each state.

(a)

\begin{tabular}{|c|c|c|c|c|c|c|c|c|}
\hline \multirow{2}{*}{ State } & \multicolumn{3}{|c|}{ Time 1} & \multicolumn{3}{|c|}{ Time 2} & \multirow{2}{*}{$\begin{array}{l}\text { Annualized } \\
\text { change }\end{array}$} & \multirow{2}{*}{$\begin{array}{c}\text { Relative change } \\
\text { (\%) }\end{array}$} \\
\hline & Trees & Sampling error & n plots & Trees & Sampling error & n plots & & \\
\hline Alabama & $1,092,781,586$ & $50,158,675$ & 4515 & $551,279,079$ & $26,847,291$ & 5375 & $-31,853,089$ & -49.6 \\
\hline Arkansas & $695,217,351$ & $32,258,085$ & 5878 & $412,492,486$ & $21,490,859$ & 5571 & $-23,560,405$ & -40.7 \\
\hline Connecticut & $2,666,645$ & $1,998,917$ & 344 & $6,018,066$ & $2,708,130$ & 352 & 159,591 & 125.7 \\
\hline Delaware & $9,936,015$ & $6,829,023$ & 200 & $3,399,814$ & $1,726,086$ & 244 & $-326,810$ & -65.8 \\
\hline Florida & $54,537,078$ & $7,182,533$ & 12,441 & $42,081,521$ & $8,832,911$ & 6781 & $-622,778$ & -22.8 \\
\hline Georgia & $810,863,469$ & $27,812,617$ & 12,015 & $469,478,198$ & $25,680,457$ & 6252 & $-18,965,848$ & -42.1 \\
\hline Illinois & $65,072,594$ & $6,299,027$ & 10,956 & 72,839,330 & $10,467,012$ & 6028 & 353,033 & 11.9 \\
\hline Indiana & $194,670,206$ & $9,188,434$ & 11,439 & $95,374,628$ & $8,936,603$ & 4644 & $-4,728,361$ & -51 \\
\hline Iowa & 421,023 & 271,728 & 12,767 & 347,740 & 400,944 & 6018 & -4311 & -17.4 \\
\hline Kansas & 239,876 & 299,221 & 14,875 & - & - & - & $-18,452$ & - \\
\hline Kentucky & $622,999,161$ & $43,859,141$ & 3239 & $343,061,256$ & $19,828,941$ & 4280 & $-15,552,106$ & -44.9 \\
\hline Louisiana & $192,997,713$ & $18,508,481$ & 2893 & $125,069,753$ & $12,982,240$ & 5449 & $-4,851,997$ & -35.2 \\
\hline Maine & 372,484 & 385,484 & 3001 & - & - & - & $-33,862$ & - \\
\hline Maryland & $71,647,439$ & $15,110,445$ & 1224 & $24,698,245$ & $6,362,268$ & 548 & $-2,347,460$ & -65.5 \\
\hline Massachusetts & - & - & - & $1,224,278$ & $1,256,109$ & 566 & 58,299 & - \\
\hline Michigan & $33,119,687$ & $5,203,103$ & 18,483 & $25,303,000$ & $4,511,525$ & 13,196 & $-558,335$ & -23.6 \\
\hline Minnesota & - & - & - & 282,382 & 255,895 & 17,855 & 16,611 & - \\
\hline Mississippi & $600,732,681$ & $30,276,927$ & 5300 & $283,426,132$ & $18,280,986$ & 5176 & $-26,442,212$ & -52.8 \\
\hline Missouri & $529,244,953$ & $15,930,273$ & 17,259 & $576,198,500$ & 23,393,659 & 7924 & $2,608,530$ & 8.9 \\
\hline Nebraska & $2,288,061$ & $1,513,095$ & 14,449 & - & - & - & $-95,336$ & - \\
\hline New Jersey & $19,876,558$ & $8,946,439$ & 644 & $10,667,028$ & $6,266,879$ & 417 & $-484,712$ & -46.3 \\
\hline New York & $31,115,655$ & $6,388,044$ & 5367 & $11,535,384$ & $4,238,100$ & 3832 & $-1,506,175$ & -62.9 \\
\hline North Carolina & $931,343,766$ & $28,871,657$ & 9373 & $359,643,076$ & $22,981,193$ & 4565 & $-25,986,395$ & -61.4 \\
\hline Ohio & $416,455,023$ & $24,904,010$ & 5056 & $120,156,133$ & $12,400,113$ & 4356 & $-19,753,259$ & -71.1 \\
\hline Pennsylvania & $199,013,009$ & $17,891,270$ & 5447 & $71,699,850$ & $13,056,543$ & 4676 & $-7,489,009$ & -64 \\
\hline Rhode Island & $3,233,847$ & $3,027,204$ & 100 & $1,289,850$ & 736,246 & 140 & $-92,571$ & -60.1 \\
\hline South Carolina & $340,599,514$ & $16,519,076$ & 7020 & $218,043,116$ & $16,505,864$ & 3416 & $-5,836,019$ & -36 \\
\hline Tennessee & $764,366,052$ & $37,836,120$ & 2950 & $315,639,335$ & $17,675,803$ & 4449 & $-24,929,262$ & -58.7 \\
\hline Texas & $158,475,178$ & $13,644,713$ & 3705 & $85,545,756$ & $8,734,222$ & 3741 & $-4,861,961$ & -46 \\
\hline Virginia & $912,976,646$ & $28,393,574$ & 7314 & $332,856,088$ & $18,273,799$ & 4585 & $-25,222,633$ & -63.5 \\
\hline West Virginia & $522,150,905$ & $32,112,281$ & 3341 & $140,680,993$ & $15,488,977$ & 1376 & $-22,439,407$ & -73.1 \\
\hline
\end{tabular}


C. M. OSWALT ET AL.

(b)

\begin{tabular}{|c|c|c|c|c|c|c|c|c|}
\hline \multirow{2}{*}{ State } & \multicolumn{3}{|c|}{ Time 1} & \multicolumn{3}{|c|}{ Time 2} & \multirow{2}{*}{$\begin{array}{l}\text { Annualized } \\
\text { change }\end{array}$} & \multirow{2}{*}{$\begin{array}{l}\text { Relative change } \\
\text { (\%) }\end{array}$} \\
\hline & $\mathrm{Mg}$ & Sampling error & n plots & $\mathrm{Mg}$ & Sampling error & n plots & & \\
\hline Alabama & $14,681,920$ & 45,285 & 4515 & $5,690,852$ & 259,079 & 5375 & $-528,886$ & -61.2 \\
\hline Arkansas & $7,175,656$ & 70,683 & 5878 & $3,092,813$ & 160,235 & 5571 & $-340,237$ & -56.9 \\
\hline Connecticut & 113,247 & 813 & 344 & 93,488 & 42,608 & 352 & -941 & -17.4 \\
\hline Delaware & 33,165 & 687 & 200 & 86,072 & 30,550 & 244 & 2645 & 159.5 \\
\hline Florida & 676,545 & 35,599 & 12,441 & 365,771 & 61,211 & 6781 & $-15,539$ & -45.9 \\
\hline Georgia & $9,585,290$ & 128,559 & 12,015 & 4,785,739 & 231,602 & 6252 & $-266,642$ & -50.1 \\
\hline Illinois & 509,127 & 5466 & 10,956 & 300,419 & 34,315 & 6028 & -9487 & -41 \\
\hline Indiana & 1,589,255 & 17,684 & 11,439 & 551,966 & 52,741 & 4644 & $-49,395$ & -65.3 \\
\hline Iowa & 1260 & 839 & 12,767 & 309 & 357 & 6018 & -56 & -75.4 \\
\hline Kansas & 525 & 27,130 & 14,875 & - & - & - & -40 & - \\
\hline Kentucky & 6,296,147 & 93,049 & 3239 & $3,615,705$ & 217,727 & 4280 & $-148,913$ & -42.6 \\
\hline Louisiana & $2,742,943$ & 91,882 & 2893 & $1,534,816$ & 149,570 & 5449 & $-86,295$ & -44 \\
\hline Maine & 811 & 259,955 & 3001 & - & - & - & -74 & - \\
\hline Maryland & 69,528 & 133,572 & 1224 & 293,671 & 65,502 & 548 & 11,207 & 322.4 \\
\hline Massachusetts & - & - & - & 12,416 & 9022 & 566 & 591 & - \\
\hline Michigan & 252,253 & 7145 & 18,483 & 91,411 & 16,089 & 13,196 & $-11,489$ & -63.8 \\
\hline Minnesota & - & - & - & 616 & 558 & 17,855 & 36 & - \\
\hline Mississippi & $9,293,321$ & 263,639 & 5300 & $2,851,748$ & 174,260 & 5176 & $-536,798$ & -69.3 \\
\hline Missouri & $4,151,419$ & 50,126 & 17,259 & 2,499,988 & 110,693 & 7924 & $-91,746$ & -39.8 \\
\hline Nebraska & 8027 & 106,323 & 14,449 & - & - & - & -334 & - \\
\hline New Jersey & 322,914 & 0 & 644 & 227,303 & 127,288 & 417 & -5032 & -29.6 \\
\hline New York & 442,769 & 623,789 & 5367 & 130,228 & 44,569 & 3832 & $-24,042$ & -70.6 \\
\hline North Carolina & $10,298,401$ & 489,489 & 9373 & $3,446,261$ & 202,293 & 4565 & $-311,461$ & -66.5 \\
\hline Ohio & 4,003,046 & 252,498 & 5056 & $1,188,839$ & 115,158 & 4356 & $-187,614$ & -70.3 \\
\hline Pennsylvania & $1,481,278$ & 437,786 & 5447 & 719,055 & 99,045 & 4676 & $-44,837$ & -51.5 \\
\hline Rhode Island & 12,960 & 318,677 & 100 & 18,859 & 9338 & 140 & 281 & 45.5 \\
\hline South Carolina & $3,920,441$ & 173,465 & 7020 & 2,098,895 & 140,715 & 3416 & $-86,740$ & -46.5 \\
\hline Tennessee & $9,592,100$ & 485,761 & 2950 & $3,429,733$ & 196,362 & 4449 & $-342,354$ & -64.2 \\
\hline Texas & $1,904,753$ & 182,551 & 3705 & 704,505 & 73,524 & 3741 & $-80,017$ & -63 \\
\hline Virginia & $7,147,407$ & 261,572 & 7314 & $2,288,775$ & 143,201 & 4585 & $-211,245$ & -68 \\
\hline West Virginia & $3,687,075$ & 352,415 & 3341 & $1,655,703$ & 186,155 & 1376 & $-119,492$ & -55.1 \\
\hline
\end{tabular}


C. M. OSWALT ET AL.

Table A2.

Mean difference between times 1 and 2, sample size, t statistic and associated p-value for number of trees and biomass by diameter class for dogwood in the Eastern United States.

\begin{tabular}{|c|c|c|c|c|c|c|c|}
\hline \multirow{2}{*}{ Diameter class } & \multirow{2}{*}{$\mathrm{n}$} & \multicolumn{3}{|c|}{ Trees (no.) } & \multicolumn{3}{|c|}{ Biomass (Mg) } \\
\hline & & Mean of difference & $t^{2}$ & $\mathrm{P}^{3}$ & Mean of difference & $\mathrm{t}^{2}$ & $\mathrm{P}^{3}$ \\
\hline 2 & 1390 & $-2,720,635$ & -21.92 & $<.0001$ & $-17,018$ & -23.04 & $<.0001$ \\
\hline 4 & 1390 & $-503,314$ & -15.34 & $<.0001$ & $-19,137$ & -17.78 & $<.0001$ \\
\hline 6 & 1390 & $-64,865$ & -11.76 & $<.0001$ & -4759 & -13.94 & $<.0001$ \\
\hline 8 & 1390 & -4932 & -4.23 & $<.0001$ & -865 & -6.34 & $<.0001$ \\
\hline 10 & 1390 & -600 & -1.83 & .0682 & -171 & -2.68 & .0075 \\
\hline 12 & 1390 & -85 & -.86 & .3914 & -46 & -1.46 & .1452 \\
\hline 14 & 1390 & 68 & 1.44 & .1507 & 30 & 1.15 & .2489 \\
\hline All stems & 1390 & $-3,294,313$ & -22.76 & $<.0001$ & $-41,884$ & -23.08 & $<.0001$ \\
\hline
\end{tabular}

${ }^{1}$ County-level mean difference of the number of dogwood stems $>2.5 \mathrm{~cm}$ (1-inch) diameter between times 1 and 2; ${ }^{2}$ Paired T-test pairing time 1 county-level estimates to time 2 county-level estimates; ${ }^{3} \mathrm{p}$-value of paired t-test. Bold numerals denotes significance at the .05 level.

Table A3.

Estimates of the number of trees and aboveground biomass of dogwood for times 1 and 2 along with associated sampling error, t statistic, p-value and percent change by diameter class.

\begin{tabular}{|c|c|c|c|c|c|c|c|}
\hline \multirow{2}{*}{ Diameter class } & Time 1 & Sampling error & Time 2 & Sampling error & \multirow{2}{*}{$\mathrm{t}^{1}$} & \multirow{2}{*}{$\mathrm{P}^{2}$} & \multirow{2}{*}{ Percent change } \\
\hline & \multicolumn{4}{|c|}{ Trees (millions) } & & & \\
\hline 2 & 7548.80 & 103.12 & 3767.08 & 67.15 & -21.92 & $<.0001$ & -50 \\
\hline 4 & 1486.86 & 34.8 & 787.31 & 22.93 & -15.34 & $<.0001$ & -47 \\
\hline 6 & 216.54 & 6.61 & 126.38 & 2.97 & -11.76 & $<.0001$ & -42 \\
\hline 8 & 23.92 & 1.49 & 17.06 & .91 & -4.23 & $<.0001$ & -29 \\
\hline 10 & 2.91 & .39 & 2.07 & .28 & -1.83 & .0682 & -29 \\
\hline 12 & .37 & .11 & .25 & .1 & -.86 & .3914 & -32 \\
\hline \multirow[t]{2}{*}{$14+$} & .02 & .02 & .11 & .06 & 1.44 & .1507 & 592 \\
\hline & \multicolumn{4}{|c|}{ Biomass (Mg) } & & & \\
\hline 2 & $39,594,515$ & 607,329 & $15,939,283$ & 324,914 & -23.05 & $<.0001$ & -60 \\
\hline 4 & $44,387,753$ & $1,105,408$ & $17,788,644$ & 573,147 & -17.78 & $<.0001$ & -60 \\
\hline 6 & $12,512,048$ & 396,567 & $5,897,061$ & 149,144 & -13.94 & $<.0001$ & -53 \\
\hline 8 & $2,788,154$ & 180,239 & $1,585,685$ & 89,260 & -6.34 & $<.0001$ & -43 \\
\hline 10 & 576,669 & 81,240 & 338,093 & 48,256 & -2.68 & .0075 & -41 \\
\hline 12 & 123,230 & 38,511 & 58,671 & 22,941 & -1.46 & .1452 & -52 \\
\hline $14+$ & 11,213 & 11,370 & 168,520 & 89,332 & 1.15 & .2489 & 1403 \\
\hline
\end{tabular}

${ }^{1}$ Paired T-test pairing time 1 county-level estimates to time 2 county-level estimates; ${ }^{2}$ p-value of paired t-test. Bold numerals denotes significance at the .05 level. 
C. M. OSWALT ET AL.

Table A4.

Mean difference between times 1 and 2, sample size, t statistic and associated p-value for number of trees and biomass by state for dogwood in the Eastern United States.

\begin{tabular}{|c|c|c|c|c|c|c|c|}
\hline \multirow{2}{*}{ State } & \multirow{2}{*}{$\mathrm{n}$} & \multicolumn{3}{|c|}{ Trees (no.) } & \multicolumn{3}{|c|}{ Biomass (Mg) } \\
\hline & & Mean of difference ${ }^{1}$ & $t^{2}$ & $\mathrm{P}^{3}$ & Mean of difference ${ }^{1}$ & $t^{2}$ & $\mathrm{P}^{3}$ \\
\hline Alabama & 67 & $-8,081,781$ & -7.69 & $<.0001$ & $-134,192$ & -8.31 & $<.0001$ \\
\hline Arkansas & 72 & $-3,927,404$ & -5.39 & $<.0001$ & $-56,716$ & -6.19 & $<.0001$ \\
\hline Connecticut & 8 & 418,917 & .84 & .4313 & -2471 & -.36 & .7328 \\
\hline Delaware & 3 & $-2,181,978$ & -2.36 & .1422 & 17,634 & 1.47 & .2795 \\
\hline Florida & 30 & $-414,954$ & -0.87 & .3917 & $-10,359$ & -1.72 & .0958 \\
\hline Georgia & 133 & $-2,567,326$ & -8.06 & $<.0001$ & $-36,091$ & -8.87 & $<.0001$ \\
\hline Illinois & 53 & 146,623 & .72 & .4747 & -3937 & -2.99 & .0043 \\
\hline Indiana & 68 & $-1,460,115$ & -4.42 & $<.0001$ & $-15,253$ & -5.18 & $<.0001$ \\
\hline Iowa & 2 & $-36,359$ & -.09 & .94 & -474 & -.61 & .6534 \\
\hline Kansas & 3 & $-79,972$ & -2.77 & .1091 & -175 & -2.35 & .143 \\
\hline Kentucky & 105 & $-2,665,048$ & -6.05 & $<.0001$ & $-25,513$ & -4.7 & $<.0001$ \\
\hline Louisiana & 44 & $-1,543,978$ & -2.46 & .018 & $-27,461$ & -3.44 & .0013 \\
\hline Maine & 1 & $-372,484$ & & & -811 & & \\
\hline Maryland & 22 & $-2,134,850$ & -3.2 & .0043 & 10,188 & 3.25 & .0038 \\
\hline Massachusetts & 1 & $1,224,278$ & & & 9022 & & \\
\hline Michigan & 35 & $-223,088$ & -.89 & .378 & -4594 & -2.12 & .0417 \\
\hline Minnesota & 1 & 282,382 & & & 558 & & \\
\hline Mississippi & 75 & $-4,231,111$ & -7.65 & $<.0001$ & $-85,890$ & -8.52 & $<.0001$ \\
\hline Missouri & 77 & 610,406 & 1.63 & .107 & $-21,442$ & -5.16 & $<.0001$ \\
\hline Nebraska & 3 & $-762,571$ & -3.35 & .0787 & -2675 & -2.42 & .137 \\
\hline New Jersey & 11 & $-837,688$ & -.76 & .4626 & -8699 & -.45 & .6629 \\
\hline New York & 30 & $-652,807$ & -2.13 & .0416 & $-10,421$ & -2.48 & .0194 \\
\hline North Carolina & 99 & $-5,774,619$ & -8.99 & $<.0001$ & $-69,219$ & -9.06 & $<.0001$ \\
\hline Ohio & 62 & $-4,778,786$ & -5.38 & $<.0001$ & $-45,395$ & -5.1 & $<.0001$ \\
\hline Pennsylvania & 59 & $-2,157,888$ & -5.09 & $<.0001$ & $-12,918$ & -4.1 & .0001 \\
\hline Rhode Island & 3 & $-648,043$ & -.49 & .673 & 1966 & .23 & .8402 \\
\hline South Carolina & 45 & $-2,722,960$ & -3.67 & $<.0001$ & $-40,473$ & -4.28 & $<.0001$ \\
\hline Tennessee & 90 & $-4,985,419$ & -7.66 & $<.0001$ & $-68,462$ & -9.16 & $<.0001$ \\
\hline Texas & 40 & $-1,823,369$ & -4.05 & .0002 & $-30,009$ & -4.96 & $<.0001$ \\
\hline Virginia & 96 & $-6,043,939$ & -12.51 & $<.0001$ & $-50,616$ & -11.64 & $<.0001$ \\
\hline West Virginia & 51 & $-7,480,127$ & -8.51 & $<.0001$ & $-39,839$ & -6.01 & $<.0001$ \\
\hline
\end{tabular}

${ }^{1}$ County-level mean difference of the number of dogwood stems $>2.5 \mathrm{~cm}$ (1-inch) diameter between times 1 and 2; ${ }^{2}$ Paired T-test pairing time 1 county-level estimates to time 2 county-level estimates; ${ }^{3} \mathrm{p}$-value of paired $t$-test. Bold numerals denotes significance at the .05 level. 
C. M. OSWALT ET AL.

Table A5.

Mean difference between times 1 and 2, sample size, $t$ statistic and associated p-value for number of trees and biomass by state and FIA unit for dogwood in the Eastern United States.

\begin{tabular}{|c|c|c|c|c|c|c|c|c|c|}
\hline \multirow{2}{*}{ State } & \multirow{2}{*}{ FIA unit code } & \multirow{2}{*}{ Unit name } & \multirow{2}{*}{$\mathrm{n}$} & \multicolumn{3}{|c|}{ Trees (no.) } & \multicolumn{3}{|c|}{ Biomass (Mg) } \\
\hline & & & & Mean of difference ${ }^{1}$ & $t^{2}$ & $\mathrm{P}^{3}$ & Mean of difference ${ }^{1}$ & $t^{2}$ & $\mathrm{P}^{3}$ \\
\hline \multirow{6}{*}{ Alabama } & 1 & Southwest-South & 5 & $-7,605,138$ & -2.59 & .0608 & $-148,496$ & -2.5 & .0669 \\
\hline & 2 & Southwest-North & 7 & $-16,365,688$ & -4.66 & .0035 & $-244,723$ & -3.67 & .0105 \\
\hline & 3 & Southeast & 21 & $-4,852,196$ & -2.69 & .0142 & $-88,654$ & -2.92 & .0084 \\
\hline & 4 & West Central & 9 & $-11,016,959$ & -3.64 & .0066 & $-188,035$ & -4.39 & .0023 \\
\hline & 5 & North Central & 15 & $-8,454,062$ & -3.47 & .0038 & $-129,189$ & -4.5 & .0005 \\
\hline & 6 & North & 10 & $-6,103,411$ & -5.75 & .0003 & $-104,343$ & -4.97 & .0008 \\
\hline \multirow{5}{*}{ Arkansas } & 1 & South Delta & 9 & $-942,188$ & -1.52 & .1672 & $-18,786$ & -2.01 & .0787 \\
\hline & 2 & North Delta & 9 & $-289,672$ & .75 & .4721 & 59 & .02 & .9872 \\
\hline & 3 & Southwest & 20 & $-3,676,100$ & -5.72 & $<.0001$ & $-36,793$ & -6.03 & $<.0001$ \\
\hline & 4 & Ouachita & 10 & $-3,613,440$ & -4.49 & .0015 & $-61,999$ & -5.5 & .0004 \\
\hline & 5 & Ozark & 24 & $-6,968,503$ & -3.66 & .0013 & $-106,631$ & -4.68 & .0001 \\
\hline Connecticut & 1 & Connecticut & 8 & 418,917 & .84 & .4313 & -2471 & -0.36 & .7328 \\
\hline \multirow[t]{2}{*}{ Delaware } & 1 & Delaware & 3 & $-2,181,978$ & -2.36 & .1422 & 17,634 & 1.47 & .2795 \\
\hline & 1 & Northeastern & 12 & 86,250 & .34 & .743 & -850 & -.37 & .722 \\
\hline \multirow[t]{4}{*}{ Florida } & 2 & Northwestern & 14 & $-965,504$ & -.98 & .3448 & $-21,616$ & -1.76 & .1012 \\
\hline & 3 & Central & 4 & 8360 & .01 & .9905 & 515 & .16 & .8826 \\
\hline & 1 & Southeastern & 16 & $-441,100$ & -1.6 & .1308 & -7177 & -3.57 & .0028 \\
\hline & 2 & Southwestern & 16 & $-907,228$ & -2.58 & .0208 & -9543 & -2.01 & .0629 \\
\hline \multirow[t]{4}{*}{ Georgia } & 3 & Central & 48 & $-1,525,543$ & -3.61 & .0007 & $-33,094$ & -4.95 & $<.0001$ \\
\hline & 4 & North Central & 32 & $-3,609,528$ & -6.36 & $<.0001$ & $-48,309$ & -6.77 & $<.0001$ \\
\hline & 5 & Northern & 21 & $-6,245,248$ & -5.59 & $<.0001$ & $-66,582$ & -4.73 & .0001 \\
\hline & 1 & Southern & 15 & 779,910 & 1.65 & .1203 & -4159 & -1.4 & .178 \\
\hline \multirow[t]{3}{*}{ Illinois } & 2 & Claypan & 17 & $-81,072$ & -.21 & .8352 & -5404 & -1.9 & .0754 \\
\hline & 3 & Prairie & 21 & $-121,400$ & -.57 & .5769 & -2593 & -2 & .0588 \\
\hline & 1 & Lower Wabash & 14 & $-2,606,899$ & -2.48 & .0277 & $-21,917$ & -2.78 & .0156 \\
\hline \multirow{3}{*}{ Indiana } & 2 & Knobs & 17 & $-3,612,894$ & -5.66 & $<.0001$ & $-39,490$ & -6.54 & $<.0001$ \\
\hline & 3 & Upland Flats & 8 & $-184,226$ & -.57 & .5886 & -4392 & -1.49 & .1806 \\
\hline & 4 & Northern & 29 & 3510 & .04 & .9708 & -826 & -1.41 & .1681 \\
\hline \multirow{2}{*}{ Iowa } & 1 & Northeastern & 1 & $-420,460$ & & & -1259 & & \\
\hline & 3 & Southwestern & 1 & 347,740 & & & 309 & & \\
\hline \multirow{2}{*}{ Kansas } & 1 & Northeastern & 1 & $-199,955$ & & & -284 & & \\
\hline & 2 & Southeastern & 2 & $-59,980$ & -1.67 & .344 & -121 & -1.37 & .4013 \\
\hline
\end{tabular}




\begin{tabular}{|c|c|c|c|c|c|c|c|c|c|}
\hline & 1 & Eastern & 8 & $-4,316,515$ & -2.68 & .0317 & $-32,230$ & -1.12 & .2995 \\
\hline & 2 & Northern Cumberland & 13 & $-5,884,127$ & -4 & .0018 & $-46,023$ & -3.04 & .0102 \\
\hline & 3 & Southern Cumberland & 12 & $-7,240,478$ & -3.72 & .0034 & $-47,961$ & -1.95 & .0777 \\
\hline \multirow[t]{6}{*}{ Kentucky } & 4 & Bluegrass & 23 & $-77,139$ & -.24 & .811 & 1974 & .86 & .4004 \\
\hline & 5 & Pennyroyal & 20 & $-1,466,521$ & -2.03 & .0565 & $-32,250$ & -2.47 & .0231 \\
\hline & 6 & Western Coalfield & 19 & $-1,759,430$ & -2.43 & .0256 & $-27,156$ & -2.53 & .0209 \\
\hline & 7 & Western & 10 & $-1,738,479$ & -1.75 & .1133 & $-13,200$ & -.87 & .4067 \\
\hline & 1 & North Delta & 6 & $-95,374$ & -.11 & .9166 & -8623 & -.98 & .3738 \\
\hline & 2 & South Delta & 8 & $1,584,953$ & 2.76 & .028 & 11,115 & 2.73 & .0294 \\
\hline \multirow[t]{3}{*}{ Louisiana } & 3 & Southwest & 10 & $-3,923,268$ & -2.89 & .0178 & $-47,262$ & -3.4 & .0079 \\
\hline & 4 & Southeast & 7 & $-3,355,577$ & -1.47 & .1928 & $-32,609$ & -2.66 & .0375 \\
\hline & 5 & Northwest & 13 & $-1,332,362$ & -1.37 & .1967 & $-41,892$ & -1.94 & .0763 \\
\hline \multirow[t]{2}{*}{ Maine } & 3 & Penobscot & 1 & $-372,562$ & & & -811 & & \\
\hline & 2 & Central & 14 & $-2,090,903$ & -2.21 & .0453 & 6702 & 2.36 & .0346 \\
\hline \multirow{3}{*}{ Maryland } & 3 & Southern & 3 & $-2,278,547$ & -1.86 & .2041 & 23,345 & 1.39 & .2991 \\
\hline & 4 & Lower Eastern Shore & 3 & $-635,148$ & -0.79 & .5137 & 10,380 & 1.74 & .2247 \\
\hline & 5 & Western & 2 & $-4,476,482$ & -1.78 & .3257 & 14,559 & 1 & .5 \\
\hline Massachusetts & 1 & Massachusetts & 1 & $1,224,278$ & & & 12,416 & & \\
\hline \multirow{2}{*}{ Michigan } & 3 & $\begin{array}{l}\text { Northern Lower } \\
\text { Peninsula }\end{array}$ & 8 & 527,934 & 1.62 & .1486 & 1172 & 1.14 & .2925 \\
\hline & 4 & $\begin{array}{c}\text { Southern Lower } \\
\text { Peninsula }\end{array}$ & 27 & $-445,613$ & -1.49 & .1472 & -6303 & -2.32 & .0288 \\
\hline \multirow[t]{3}{*}{ Minnesota } & 3 & Central Hardwood & 1 & 282,382 & & & 616 & & \\
\hline & 1 & Delta & 7 & $-2,290,818$ & -1.19 & .2785 & $-72,744$ & -2.39 & .0543 \\
\hline & 2 & North & 26 & $-3,415,566$ & -4.01 & .0005 & $-79,410$ & -4.28 & .0002 \\
\hline \multirow[t]{5}{*}{ Mississippi } & 3 & Central & 14 & $-3,126,130$ & -3.42 & $<.0001$ & $-78,748$ & -6.77 & $<.0001$ \\
\hline & 4 & South & 17 & $-5,155,069$ & -4.04 & .0009 & $-78,304$ & -3.42 & .0035 \\
\hline & 5 & Southwest & 11 & $-7,371,896$ & -4.49 & .0012 & $-130,391$ & -4.15 & .002 \\
\hline & 1 & Eastern Ozarks & 14 & $-1,095,115$ & -.98 & .3457 & $-71,175$ & -6.84 & $<.0001$ \\
\hline & 2 & Southwestern Ozarks & 12 & $3,803,624$ & 2.74 & .0193 & $-19,465$ & -1.55 & .1493 \\
\hline \multirow[t]{3}{*}{ Missouri } & 3 & Northwestern Ozarks & 11 & $1,718,808$ & 1.72 & .1157 & $-13,792$ & -1.35 & .2073 \\
\hline & 4 & Prairie & 21 & $-150,491$ & -1.11 & .2789 & $-1,468$ & -2.28 & .0336 \\
\hline & 5 & Riverborder & 19 & 49,619 & .18 & .8554 & $-12,553$ & -3.94 & .001 \\
\hline Nebraska & 1 & Eastern & 3 & $-762,571$ & -3.35 & .0787 & -2675 & -2.42 & .137 \\
\hline New Jersey & 1 & New Jersey & 11 & $-837,688$ & -.76 & .4626 & -8699 & -.45 & .66 \\
\hline \multirow{7}{*}{ New York } & 1 & Adirondack & 2 & $-315,089$ & -15.18 & .0419 & -658 & -2.56 & .2371 \\
\hline & 2 & Lake Plain & 4 & $-603,804$ & -.77 & .4951 & $-11,570$ & -1.38 & .262 \\
\hline & 3 & Western Adirondack & 1 & 583,387 & & & 867 & & \\
\hline & 5 & Southwest Highlands & 3 & $-970,217$ & -2.42 & .1369 & -8747 & -1.54 & .2638 \\
\hline & 6 & $\begin{array}{l}\text { South-Central } \\
\text { Highlands }\end{array}$ & 6 & $-845,510$ & -3.23 & .0233 & -9733 & -2.8 & .0378 \\
\hline & 7 & Capitol District & 6 & 597,749 & 1.51 & .1911 & -987 & -.5 & .6385 \\
\hline & 8 & $\begin{array}{c}\text { Catskill-Lower } \\
\text { Hudson }\end{array}$ & 8 & $-1,590,625$ & -1.72 & .129 & $-21,916$ & -1.5 & .1774 \\
\hline
\end{tabular}


Continued

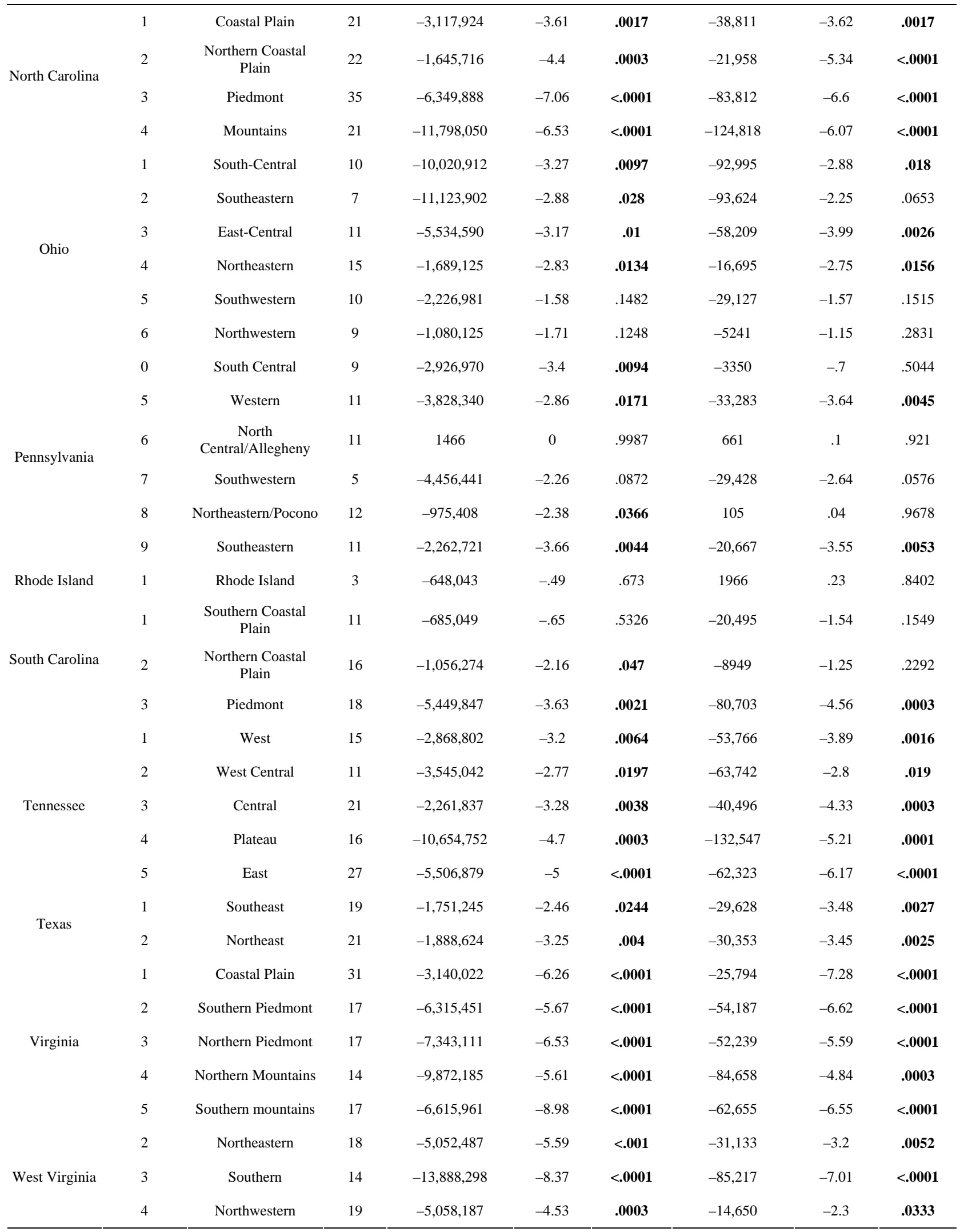

${ }^{1}$ County-level mean difference of the number of dogwood stems $>2.5 \mathrm{~cm}$ (1-inch) diameter between times 1 and 2; ${ }^{2}$ Paired T-test pairing time 1 county-level estimates to time 2 county-level estimates; ${ }^{3}$ p-value of paired $t$-test. Bold numerals denotes significance at the .05 level. 